\title{
The Customary Philosophy of the Anak Dalam Tribe as Part of the Soul of the Mation's Law
}

\author{
Muhamad Erwin $^{1, *}$ Ahmad Taqwa ${ }^{2}$ Dicky Seprianto ${ }^{3}$ Ahmad Zamheri ${ }^{3}$
}

\author{
${ }^{I}$ State Polytechnic of Sriwijaya, Palembang, Indonesia \\ ${ }^{2}$ Electrical Engineering Departemet State Polytechnic of Sriwijaya, Palembang, Indonesia \\ ${ }^{3}$ Mechanical Enginering Departement State Polytechnic of Sriwijaya Palembang, Indonesia \\ *Corresponding author. Email: erwin_muhamad@ymail.com
}

\begin{abstract}
In the soul of the customary law of the Anak Dalam Tribe in Bukit Duabelas National Park is closely related to the traditional teachings of the ancestors and in the balance of his life with the jungle of Bukit Duabelas. The nuance of the soul of law takes place by basing on the existence, source of knowledge, the structure of knowledge, truthfulness of knowledge, and values that live in the Anak Dalam Tribe in Bukit Duabelas National Park. In this connection, this paper will uncover this phenomenon through an investigation based on the philosophy of existence, the philosophy of knowledge, and the philosophy of customary law values which can then be used as legal ideals.
\end{abstract}

Keywords: spirit of law, customary law, Suku Anak Dalam, philosophy of existence, philosophy of knowledge, philosophy of values, legal ideals.

\section{INTRODUCTION}

Anak Dalam people in Bukit Duabelas National Park is one of the federations of customary law in Indonesia that obtains juridical protection in the legal system in Indonesia. This is none other than because the paradigm of Indonesian law is based on the philosophy of Pancasila which was historically born from the diversity of cultures and customary law in Indonesia. In other words, the values contained in the culture and customary law in Indonesia are synthesized into the values of Pancasila law as the basis and source of law for the existence and creation of various laws and regulations in Indonesia.

In its later development, there was a shift in the legal paradigm in Indonesia which was more influenced by culture and legal systems from outside Indonesia, be it Continental Europe or the rule of law. This is none other than because the Pancasila legal system is prismatic as is the case with customary law which is open to culture and law from outside as long as it is beneficial and does not conflict with traditions that have been passed down from generation to generation from the ancestors of the Indonesian nation. In other words, the nature of openness in the Pancasila legal system and customary law in Indonesia is limited by its traditional (hereditary) nature. This means that foreign cultural values that are contrary to traditional Indonesian cultural values may not be absorbed from the legal system. For example, individualistic cultural values that are contrary to traditional Indonesian cultural values which are communal in nature, must be removed from the Indonesian legal system. But unfortunately, this is difficult to avoid because basically the conceptualization of state law is basically based on a modern legal paradigm which tends to nullify the existence of traditional laws that are considered primitive and outdated. The elimination of the existence of customary laws in Indonesia which are traditional in nature is also caused by the drafting of state law which tends to have a positivist paradigm so that in the end Indonesian traditional laws which are mostly unwritten lose their strength in law enforcement, especially with the legal stratification paradigm which tends to determine law the state is above customary laws. Even though in fact, it is not as stipulated in the provisions Article 18B verse (2) Constitution Law 1945. This means that as long as it is still alive and in accordance with the principles of the Unitary State of Indonesia, the customary law is recognized and remains valid in each of these regions. Or in other words, the enforcement of state law must respect local customary laws.

Based on the description above, it can be concluded that the drafting of state law in Indonesia based on the paradigm of Pancasila law is basically the 
institutionalization of plural culture and customary law throughout Indonesia into the concept of a unitary law state. The conceptualization into a state legal system as intended is not to replace or display the existence of local culture and customary laws that existed before the establishment of the state, but to organize legal diversity in a legal system that is acceptable in local culture and customary law when applied or in enforcement. the law. Thus, the cultural values of Pancasila law have a very important role in the basis and as a source of law for any legislation in Indonesia. So that state law can run harmoniously and in harmony with local culture and customary law. It is possible if then the state law is accepted by the local community to replace the existing customary law because of its culture and open legal nature. It becomes difficult if the paradigm of state law is not in line with Pancasila which in turn leads to inconsistency with customary law which in some places is still held by local communities because of its traditional nature as found in some customary law communities who still adhere to legal traditions that have been passed down hereditary, such as the Suku Anak Dalam in Bukit Duabelas National Park, Jambi Province.

It should be noted that the ideals of the Indonesian nation's law are expressed in the fourth paragraph The Opening of Constitutional Law 1945 not to unite the diversity of Indonesian cultures and laws into one legal system of the unitary state of the Republic of Indonesia, but for ".....protect the entire nation of Indonesia and all spilled Indonesian blood...", including protecting cultural diversity and customary law in Indonesia as regulated in Article 18B verse (2) Constitutional Law 1945. Thus, the existence of indigenous peoples who are still alive and well preserved up to now, not only must be respected, but also can be a source of learning for all Indonesian people to recognize the values of Pancasila law, which are rooted in the culture and customary laws that are spread out. throughout Indonesia. These cultural values and customary laws make the Indonesian legal system have its own characteristics (an sich) which must continue to be understood and passed on hereditary.

Moving on from the above thought, the author is interested in conducting research on customary law institutions with the case study of the Suku Anak Dalam in Bukit Duabelas National Park, as one of the indigenous peoples whose authenticity is still maintained today. However, in some groups, there has been a mixture of cultures with local communities whose own culture has also begun to be eroded by globalization and the times. Meanwhile, the customary law itself is starting to disappear, so the only law that is enforced in the area is state law. This research in itself is not intended to stop the flow of change or preserve the legal culture of Anak Dalam Tribe like a cultural heritage, but to save the noble values contained therein. The noble values contained in the traditional law culture of the Suku Anak Dalam must not only be saved, but also preserved as a reflection of the noble values of the nation's culture, namely Pancasila. Given that researchers are lecturers of Basic Citizenship Education
Courses, therefore, this research is of important value in understanding the noble values contained in Pancasila as a legacy of customary law cultures throughout Indonesia, one of which is the indigenous peoples of the Anak Dalam Tribe in Bukit Duabelas National Park. The selection of this case study itself is based on the consideration of the authenticity of the customary law institutions which are still maintained and are still being applied in most of the Orang Rimba groups scattered in the Bukit Duabelas National Park area, Jambi Province.

Reflecting on the background description, the focus of the study in this study is the formulation of the following problems:

1. What is the philosophy of the existence of the adat law of the Suku Anak Dalam in Bukit Duabelas National Park as part of the soul of the nation's law?

2. What is the philosophy of knowledge of the indigenous peoples of the Suku Anak Dalam in Bukit Duabelas National Park as part of the soul of the nation's law?

3. What is the philosophy of the customary law values of the Suku Anak Dalam in Bukit Duabelas National Park as part of the soul of the nation's law?

\section{LITERATURE REVIEW}

\subsection{The existence of customary law in philosophy and legal theory}

Customary law is an inseparable part of the culture of Indonesian society. Long before the application of colonial law in Indonesia, our ancestral communities followed their own legal system. Even though the customary law that applies in Indonesia with cultural elements is more local than colonial law which is universal in nature, behind its localization customary law is able to accommodate and even require the diversity of this nation. [1]

The fact of the existence of customary law that has lived in Indonesia for a long time was also revealed by Soepomo as follows:

It is something that can be agreed by the public that customary law is the oldest law in Indonesia. The existence of this law can be said to be as old as civilization in the archipelago. It is said that this law is a law that is deeply rooted in traditional culture, and embodies the real feeling of law from the people because it is "living law" [2].

According to Suriyaman Mustari Pide, customary law is a reflection of cultural ideas consisting of cultural values, norms, and rules that are interrelated with one another by which it becomes a system and has sanctions [3]. As a legal system that exists in Indonesia, customary law was originally born from a natural awareness of the importance of laws that govern every 
aspect of social life. According to Sudikno Mertokusumo, this arrangement is because humans in society need protection against various interests. Protection of these interests will be achieved if there are guidelines or living regulations that determine how humans should behave in society so as not to harm others and themselves. Guidelines, standards, or measures for behaving or behaving in life together are called social norms or rules [4].

Pancasila as the distinctive character of the Indonesian nation is inseparable from its source of value which comes from customary law as the unique law of the Indonesian nation. Customary law as a unique law of the Indonesian nation can be seen from what Dominikus Rato has stated below [5]:

Every nation or society has its own culture. Therefore, each society has its own laws that are different from one another. This difference shows that each society has its own characteristics as the identity of the nation concerned. This characteristic is called local genius or local prudencia or local wisdoms. This culture is what distinguishes the Indonesian nation from other nations, the laws of the Indonesian nation and the laws of other nations. The unique law of the Indonesian nation is Customary Law.

Customary Law in traditional style [6], religious magic, and open to elements of a good nature, combined through deliberation which emphasizes the principle of togetherness (communal) produced a sublime agreement (modus vivendi) of Indonesian which concrete \& visual in the form of its distinctive legal culture (an sich), namely Pancasila as the basis for the formation of the legal system in Indonesia. Historically, the values of customary law as the basis of unity for the Indonesian state have been formulated in a complete text Youth Congress Decision in 1928. The formula is written as follows:

issue a belief that Indonesian unity is strengthened by paying attention to the basis of unity, will, history, language, customary law, education and scouting

This formulation shows that there is a common perception that behind the diversity of customary laws in Indonesia, there are values that reflect the existence of equality that underlies unity for all Indonesian people. This means that there is a common thread drawn from the diversity of customary laws that live in the archipelago. Friedrich Carl von Savigny called it by the term volkgeist, namely the soul of the nation or the spirit of the society in which the law is born, lives, grows and develops. Regarding the form and content of that geestesstructure (psychiatric structures), F. D. Holleman mentions that there are four characteristics of customary law, namely: religious magic, communal, cash, and concrete [7].
Meanwhile, when viewed philosophically (from the ontological, epistemological, and axiological aspects), customary law is born from the values natuur and culture, then lowered into the form of ethical standards which are further explained in the rules which become the basis for real behavior.

\subsection{Karakteristik Hukum Adat}

Meanwhile, when viewed from this way of thinking, customary law has the following features or characteristics:

- traditional, hereditary from the time of the ancestors to the present day offspring, whose condition is still valid and maintained by the community;

- religious, religious magical in nature, which means that legal behavior or legal rules are related to belief in the unseen and based on the teachings of Almighty God;

- - togetherness, communal in nature, which means that in customary law mutual interests are prioritized in which personal interests are dominated by common interests;

- concrete and visual, meaning that customary law is clear, real, tangible, while the visual style means that customary law is visible, open, and not hidden;

- open and simple, meaning that customary law can accept elements that come from outside, provided that it does not conflict with the spirit of the customary law itself; can change and adapt, customary law is a law that has lived and applied in Indonesian society from the past until now, which in its growth and development is constantly undergoing a process of change, thickening and thinning;

- Not codified, not written, therefore customary law is easy to change and can adapt to community development;

- Deliberation and consensus, customary law essentially prioritizes deliberation and consensus, whether within the family, kinship, neighborliness, starting a job or ending work, especially those that are "judicial" in resolving disputes between one another, the way of settlement is prioritized harmoniously and peacefully with deliberation and consensus, with mutual forgiveness, not just hastily, the dispute is immediately brought or conveyed to the state court [8].

With the various characteristics of customary law thinking, there are three bonds as principles in customary law that the researchers extracted from natuur and cultuur as a source of value, then it is lowered to the magical, religious, communal, concrete, and cash way of thinking of customary law. 


\section{RESEARCH METHODOLOGY}

The legal research method used to answer the problems in this study is to use the socio-legal method which combines legal research and social studies of law. It is seen in this way, because it departs from the idea that law as nomus and norm with the law as a social living space is a unit that is always in touch.

\section{DISCUSSION}

4.1. The philosophy of the existence of the Anak Dalam Tribe in Bukit Duabelas National Park as part of the soul of the nation's law

Search of existence (teachings of things exist) Customary law is a research on the "essence" of customary law [9]. Finding out what the essence of customary law is is the same as finding out what customary law is?. Essence is the same as the deepest cause of something. Essence can also mean the existence of everything in which there is substance and accident. Substance is something that underlies quality, whereas accident is a particular property of the substance. Essence can easily be interpreted as what something is?

Finding for what is customary law according to the Suku Anak Dalam community means looking for what is the substance and accuracy of their customary law. The substance of law in the tribal customary law paradigm lies in their own customs. The customs of the Anak Dalam Tribe occurs from the life situation of the Anak Dalam Tribe when dealing with the natural conditions of Bukit Duabelas, so that the custom in the philosophy of the existence of the Anak Dalam Tribe customary law means that the Anak Dalam Tribe is what makes the custom "exist" for the existence of the Anak Dalam Tribe itself.

With this understanding, it is shown based on the nature that the tribal laws of the Inner Children are as a result of hereditary inheritance from their very old ancestors. Meanwhile, the understanding that cannot be abandoned is that the results of the legal building inherited from their ancestors are the collective will of the Suku Anak Dalam community to continue to be perpetuated as a guide in the life of the Suku Anak Dalam. Because it has become a collective agreement to be preserved in their own lives, there is a belief that every person in the Suku Anak Dalam community in Bukit Duabelas National Park must serve the customary law itself.

Thus the placement of the philosophy of existence (ontology) of the life of the Anak Dalam Tribe in Bukit Duabelas National Park in meaning (substance) lies in the understanding that they live in the jungle of Bukit Duabelas. Meanwhile, their life uniqueness (accident) is different from outside society by having its own peculiarities. Anak Dalam Tribe in Bukit Duabelas National Park believes that by maintaining a distance into the jungle and maintaining the existence of symbols and attributes of life based on the teachings of ancestral customary law is an effort to maintain the position that they are "exist" and "have a distinctive character".

\subsection{The philosophy of knowledge of the Customary Law of the Anak Dalam Tribe in Bukit Duabelas} National Park as part of the Soul of the Nation's Law

The philosophy of life knowledge of the Anak Dalam Tribe in Bukit Duabelas National Park, in structure of knowledge, is in the form of a hierarchy or top-down arrangement, where the initial knowledge comes from the divine realm or what they call it halom bahelo. Subsequently passed down through the intermediate realm they call halom dewo. Then from the unseen realm was captured by the Anak Dalam Tribe community through natural signs that appeared on Bukit Duabelas or what they called halom rimba. Furthermore, from the catch of the souls of the Orang Rimba community about halom rimba is translated to be set as guidelines in how they should and should not behave or what they call it halom nio (realm of reality). From halom nio then develops customarily in the same pattern in the form of customary law. The philosophy of life knowledge of the Suku Anak Dalam in Bukit Duabelas National Park in terms of knowledge of the truth can be proven by truth in conformity with reality, truth because it has been tested since the past, truth over practice, truth over peculiarities. The truth of conformity with reality can be proven from the fact that the fruit trees inherited from their ancestors in the Bukit Duabelas forest, which until now have been so real and can be enjoyed by them. Through the truth because it has been tested since the past, because they see Bukit Duabelas as tanoh peranoon (birth place), tanoh beghumah (housing place), tanoh pasoghon (funeral place) since their ancestry age. Based on the truth of practice, so far they have been able to manage Bukit Duabelas forest based on their customary law wisely and with strict restrictions. Furthermore, regarding the truth of the uniqueness, it can be proven through their seloko which states that the Orang Rimba live in the jungle with "Cikai leaves as roof, tree bark as wall, turf as floor, drink from tree knob, deer as our buffalo, roe as our goat, bird as our chicken". Whereas those who live in the hamlet according to the Orang Rimba have a life pattern: "Bepadang pinang bepadang kelapo, besunat bebersihan, mengaji dan besekoloh, beternak kambing, beritik berangso, belamun bedusun, berumah betetanggo".

\subsection{The philosophy of value of the Customary Law of the Anak Dalam Tribe in Bukit Duabelas National Park as part of the Soul of the Nation's Law}

The philosophy of the values of life of the Anak Dalam Tribe in Bukit Duabelas National Park is mainly present in the divine value, the value of harmony, the value of togetherness, the value of justice and human values. From the perspective of the Orang Rimba community, Bukit Duabelas is a bedewo (praying) place, then therein lies the sacred function that leads to the divine value. 
From the perspective of the Orang Rimba community, Bukit Duabelas is a place for hunting, gathering, bebalai (marriage place), belangun (mourning), bepekat berunding (conference), then there lies the social function that leads to the value of harmony, the value of togetherness and the value of justice. From the perspective of the Orang Rimba community, Bukit Duabelas is a place for beghumo (housing) dan beumo (farming), then there lies the welfare function that leads to human values.

Meanwhile, the philosophy of the life goal of the Anak Dalam Tribe in Bukit Duabelas National Park as a value in their life and after their life is to be accepted by God. In the understanding of the Anak Dalam Tribe community if they can live in harmony with the jungle of Bukit Duabelas and in harmony with adat lamo peseko usang (ancestral heritage customary law), then the Orang Rimba will be good and not qualified. If on the principle of life and then manifested in such a pattern of life, then the Orang Rimba will be accepted by God.

\subsection{The Relationship between the Traditional Law Philosophy of the Anak Dalam Tribe and the Philosophy of Pancasila}

Pancasila is considered as a distinctive character of the Indonesian nation and is inseparable from its source of value which comes from customary law as the unique law of the Indonesian nation.

Traditional traditional law styles (hereditary, religious magic and open to good character elements, are combined through deliberation that emphasizes the principle of togetherness (communal) to produce a noble agreement (modus vivendi) the concrete and visual Indonesian nation in the form of its distinctive legal culture (an sich), namely Pancasila as the basis for the formation of the legal system in Indonesia.

Pancasila as a legal culture in the national legal system is nothing but the drafting of customary law from all regions of the archipelago which is generally unwritten. So that internally, the Indonesian legal system based on Pancasila contains the concept of pluralism in its legal paradigm, which is adopted for the sake of achieving national integration that can provide overall justice. Meanwhile externally, according to Satjipto Rahardjo, the existence of Pancasila reflects the uniqueness of the Indonesian nation which is full of kinship and mutual cooperation which therefore becomes different from other legal systems. [10].

From the investigation of how the seeds of customary law are then introduced into the spirit of Pancasila law, the relationship between the two can be concluded as follows:

- from a religious magical paradigm in customary law then transforming into a divine value in the first principle of Pancasila;
- from the moral wisdom paradigm in customary law then transforms into human values in the second principle of Pancasila;

- from the mutual cooperation paradigm in customary law then transformed into a national value in the third principle of Pancasila;

- from the paradigm of deliberation to reach consensus in customary law then it is translated into a populist value in the fourth principle of Pancasila;

- and from the communal paradigm in customary law then the value of social justice is transformed into the fifth principle of Pancasila.

\section{CONCLUSIONS}

The essence of the right to the living space of the Suku Anak Dalam in the Bukit Duabelas forest basically lies between the (synthesis) understanding of the substance on the one hand and the understanding of the distinctive nature (accidency) of the relationship pattern on the other. This understanding is supported by the viewpoint of the Anak Dalam Tribe towards the Bukit Duabelas forest, which is not only seen as the material from which the cosmos is formed, but is also seen as 'exist' which enables it to be what it is.

The source of knowledge of the adat law of the Anak Dalam Tribe of the right to their living space in Bukit Duabelas is to depart from their appreciation of the nature of their shared values 'halom rimbo' (Bukit Duabelas jungle) which is his traditional living space. Meanwhile, the construction of the epistemological thinking of the "truth of knowledge" of the tribal law of the Anak Dalam Trtibe of the right to their living space in Bukit Duabelas, where according to the Orang Rimba: benor itu beik (true is good). This knowledge occurs because the Suku Anak Dalam community feels aware of their interactions with the Bukit Duabelas forest as their living space through humanist, holistic, responsibility and contextualized principles.

From all descriptions of the construction of the tribal customary law axiology of the Anak Dalam Tribe, both in the context of value as a function and value as a goal in looking at the relationship between the Anak Dalam Tribe and the right to their living space in the Bukit Duabelas jungle, it can be concluded that basically between values as the use and value as the goal of the law wisdom of the Anak Dalam Tribe in Bukit Duabelas National Park basically has a relationship between one value and another. 


\section{REFERENCES}

[1] Suriyaman Mustari Pide. (2014). Hukum Adat Dahulu, Kini dan Akan Datang. Jakarta: Prenadamedia Group. pp. 20.

[2] Soepomo, dalam Joeni Arianto Kurniawan. (2013). Gagasan Membangun (kembali) Ilmu Hukum Adat Normatif: Konseptualisasi Mohammad Koesnoe tentang Hukum Adat sebagai Dasar Hukum Nasional Indonesia, artikel dalam buku Mohammad Koesnoe dalam Pengembaraan Gagasan Hukum Indonesia. Jakarta: Epistema Institute dan Huma. pp. 99.

[3] Suriyaman Mustari Pide. Op.Cit. pp. 20-21.

[4] Sudikno Mertokusumo. (2010). Mengenal Hukum Suatu Pengantar. Yogyakarta: Cahaya Atma Pustaka. pp. 5.
[5] Dominikus Rato. (2014). Hukum Adat di IndonesiaSuatu Pengantar. Surabaya: Laksbang Justitia. pp. 2.

[6] Hilman Hadikusuma. (1992). Pengantar Ilmu Hukum Adat Indonesia. Bandung: Mandar Maju. pp. 33.

[7] Dominikus Rato. Op.Cit. pp. 62.

[8] C. Dewi Wulansari. (2012). Hukum Adat IndonesiaSuatu Pengantar. Bandung: PT Refika Aditama. pp. 1521.

[9] I Dewa Gede Atmaja. (2013). Filsafat Hukum Dimensi, Tematis dan Historis. Malang: Setara Pers. pp. 12.

[10] Moh. Mahfud MD. (2011). Perdebatan Hukum Tata Negara Pasca Amandemen Konstitusi. Jakarta: PT RajaGrafindo Persada. pp. 7. 